\title{
Dolphins and Human Flourishing: A Novel Application of the PERMA Model
}

Rachel M. Yerbury and William E. Boyd

Southern Cross University, Department of Environment, Science and Engineering, Lismore, Australia.

\section{Abstract}

Humans and nonhuman animals belong to a network of living things that have existed and interacted for millennia. The Biophilia hypothesis highlights the innate human need for nature contact and connection to ensure human well-being. Evidence suggests that contact with nature and its components, including animals, can both enhance well-being and encourage human concern for nature. The current study details the human wellbeing impact of animals, specifically dolphins. Exploration of eight key informant narratives examined the research question, "How do interactions with wild dolphins affect human wellbeing?" Analyses reveal various subthemes clustered into five main themes: Connectedness, Relationships, and Reciprocity; Emotion and Aliveness; Meaning and Making Sense; Accomplishment and Intention; and Harmony and Engagement. There are strong parallels between the identified themes and Seligman's PERMA model. Interpretation of how wildlife experiences benefit humans concluded that the features of life necessary for human flourishing also characterize people's experience with wild dolphins. Practical implications for well-being benefits include health practitioner use of "nature prescriptions" and "wildlife prescriptions," which may in turn foster a sense of responsibility and care for nature. However, the parallel dolphin well-being needs to be considered and a balanced and ecocentric view achieved. These areas warrant further research. Key Words: Well-being-PERMA-Nature-Biophilia-Wild animals-Humananimal interactions-Flourishing.
Introduction

Well-being and flourishing

W ell-being refers to the extent an individual is coping and thriving in everyday life. High levels of wellbeing are referred to as "flourishing" (Seligman, 2011), enhanced by meaningful and satisfying relationships, purpose in one's life, and psychological growth (Maslow, 1954; Rogers, 1977). The relationship between human well-being and contact with animals is well established (Geist, 2013; Kellert, 1996; Melson, 2003; Myers \& Saunders, 2002). We explore the human well-being benefits of nature through contact between people and wild dolphins; the term "human-dolphin interaction" refers here to the human experience of the interaction. We recently highlighted the dolphin's perspective and well-being in human-dolphin interactions, both in the wild (Yerbury \& Boyd, 2018b) and in captivity (Yerbury, Boyd, Lloyd, \& Brooks, 2017). While beyond the boundaries of this study, the authors espouse an ecocentric view which balances the rights and well-being of both humans and wildlife. A broad understanding of the humandolphin interface is necessary to conceptualize the processes by which human-animal interactions enhance human well-being within an ecocentric framework; this paper extends our previous work (Yerbury \& Boyd, 2018a) and adds further reason for future studies to better embrace an ecocentric approach in considering the well-being implications of human-animal interactions.

\section{Human well-being and human-animal contact}

As part of searching for connection with nature, Kellert (1996) discusses human craving for affiliation and emotional bonding with animals, particularly as the increasingly urban environment reduces opportunity for regular nature contact (Hartig \& Kahn, 2016). Human-animal connections help humans discover themselves relative to the world, notably through feeling bonded and mutually loved 


\begin{tabular}{|c|c|c|c|c|c|c|}
\hline $\begin{array}{l}\text { INTERVIEWEE } \\
\text { PSEUDONYM }\end{array}$ & $\begin{array}{l}\text { GENDER / } \\
\text { AGE } \\
\text { (YEARS) }\end{array}$ & \begin{tabular}{c|} 
YEAR(S) \\
OF DOLPHIN \\
INTERACTION
\end{tabular} & $\begin{array}{c}\text { YEAR OF INTERVIEW } \\
\text { AND METHOD / } \\
\text { INTERVIEW LENGTH } \\
\text { (INTERVIEW LOCATION) }\end{array}$ & $\begin{array}{l}\text { TYPE OF CONTACT } \\
\text { WITH DOLPHINS } \\
\text { DESCRIBED } \\
\text { IN THE NARRATIVE }\end{array}$ & $\begin{array}{l}\text { LENGTH OF } \\
\text { INTERACTION TIME } \\
\text { WITH DOLPHIN(S) } \\
\text { IN THE NARRATIVE }\end{array}$ & $\begin{array}{l}\text { AREA WHERE } \\
\text { CONTACT } \\
\text { OCCURRED }\end{array}$ \\
\hline Jacomo & $M / 41$ & 2009 & $\begin{array}{l}2015 \\
\text { In person / } 41 \text { min } \\
\text { (NSW, Australia) }\end{array}$ & $\begin{array}{l}\text { In-water interactions with a wild } \\
\text { female solitary sociable bottlenose } \\
\text { dolphin "Dusty" }\end{array}$ & $\begin{array}{l}\text { Daily for } 1 \text { week, several } \\
\text { minutes to several hours } \\
\text { each day }\end{array}$ & $\begin{array}{l}\text { West of County Clare, } \\
\text { Ireland }\end{array}$ \\
\hline Molly & $F / 17$ & 2009 & $\begin{array}{l}2016 \\
\text { In person / } 22 \mathrm{~min} \\
\text { (NSW, Australia) }\end{array}$ & $\begin{array}{l}\text { In-water interactions with a wild } \\
\text { female solitary sociable bottlenose } \\
\text { dolphin "Dusty" }\end{array}$ & $\begin{array}{l}\text { Daily for } 1 \text { week, several } \\
\text { minutes to several hours } \\
\text { each day }\end{array}$ & $\begin{array}{l}\text { West of County } \\
\text { Clare, Ireland }\end{array}$ \\
\hline Khaleesi & $F / 35$ & 2013 & $\begin{array}{l}2016 \\
\text { In person / } 31 \mathrm{~min} \\
\text { (NSW, Australia) }\end{array}$ & $\begin{array}{l}\text { In-water interaction with a wild } \\
\text { female solitary bottlenose dolphin }\end{array}$ & Once for $2 \mathrm{hr}$ & $\begin{array}{l}\text { NSW South Coast } \\
\text { (East coast of } \\
\text { Australia) }\end{array}$ \\
\hline Becky & F/60s & 2013 & $\begin{array}{l}2015 \\
\text { In person / } 52 \text { min } \\
\text { (NSW, Australia) }\end{array}$ & $\begin{array}{l}\text { Daily above-water watching and } \\
\text { interacting with a wild female } \\
\text { solitary sociable bottlenose dolphin }\end{array}$ & $\begin{array}{l}\text { Almost daily contact of } \\
\text { varying time length, over } \\
\text { a period of several months }\end{array}$ & $\begin{array}{l}\text { NSW South Coast } \\
\text { (East coast of } \\
\text { Australia) }\end{array}$ \\
\hline Anne & $\mathrm{F} / 30 \mathrm{~s}$ & 2010 & $\begin{array}{l}2015 \\
\text { Skype / } 33 \mathrm{~min} \\
\text { (to New Zealand) }\end{array}$ & $\begin{array}{l}\text { In- and above-water interactions } \\
\text { with and filming female solitary } \\
\text { bottlenose dolphin "Moko" }\end{array}$ & $\begin{array}{l}\text { Regular contact for } \\
6 \text { months of varying } \\
\text { time lengths }\end{array}$ & $\begin{array}{l}\text { East Coast of North } \\
\text { Island, New Zealand }\end{array}$ \\
\hline Mark & $\mathrm{M} / 73$ & 1990-1993 & $\begin{array}{l}2015 \\
\text { In person / } 37 \mathrm{~min} \\
\text { (SA, Australia) }\end{array}$ & $\begin{array}{l}\text { Intensive interaction with a male } \\
\text { wild solitary sociable bottlenose } \\
\text { dolphin "Jock" }\end{array}$ & $\begin{array}{l}\text { Regular contact for } \\
3 \text { years often for hours } \\
\text { in a day }\end{array}$ & $\begin{array}{l}\text { Coast of South } \\
\text { Australia }\end{array}$ \\
\hline Brenda & $F / 47$ & $1990 \mathrm{~s}-2000 \mathrm{~s}$ & $\begin{array}{l}2016 \\
\text { Skype / } 40 \text { min } \\
\text { (to SA, Australia) }\end{array}$ & $\begin{array}{l}\text { Volunteer in observational data } \\
\text { collection (above water) and caring } \\
\text { for River dolphins }\end{array}$ & $\begin{array}{l}\text { Regular contact for more } \\
\text { than } 20 \text { years of varying } \\
\text { time lengths }\end{array}$ & $\begin{array}{l}\text { Port River, Adelaide, } \\
\text { South Australia }\end{array}$ \\
\hline Jim & $\mathrm{M} / 60 \mathrm{~s}$ & $1990 \mathrm{~s}-2000 \mathrm{~s}$ & $\begin{array}{l}2016 \\
\text { Skype / } 66 \mathrm{~min} \\
\text { (to VIC, Australia) }\end{array}$ & $\begin{array}{l}\text { Involvement in dolphin research, } \\
\text { rescue, and education (both above } \\
\text { and under water) }\end{array}$ & $\begin{array}{l}\text { Regular contact with } \\
\text { dolphins for } 20 \text { years of } \\
\text { varying time lengths }\end{array}$ & $\begin{array}{l}\text { Victorian Coast, } \\
\text { Australia }\end{array}$ \\
\hline
\end{tabular}

NSW, New South Wales; SA, South Australia; VIC, Victoria.

(Kellert, 1996; Myers \&t Saunders, 2002). In general, animals can meet human needs of affiliation and interaction, reduce stress, increase responsibility, and promote positive emotions and healing (Beetz, Uvnas-Moberg, Julius, \& Kotrschal, 2012; Kahn, 1997; Katcher \&t Wilkins, 1993; Walsh, 2009). In particular, contact with wildlife promotes positive moods and attitudes (Frumkin, 2001; Muloin, 1998; Weiler, Ham, \& Smith, 2011). Specifically, wild dolphin interactions enhance people's emotional states (Curtin, 2006; DeMares, 2000; Myers \& Saunders, 2002), create nature connections or bonds (Curtin \& Kragh, 2014; Wiener, 2013) and decrease anxiety and stress (Webb \& Drummond, 2001). Despite these benefits, wildlife interactions are not one-way, and neither should wildlife be used as a commodity or negatively impacted in the pursuit of human wellbeing (Burns, 2015; Yerbury \&t Boyd, 2018b; Yerbury et al., 2017).

\section{Methods and Analyses}

As part of the first author's PhD study, interviews were conducted under human research ethics approval ${ }^{1}$. Ten participants with dolphin experience (Table 1), were recruited by purposive sampling (Patton, 1999). Participants were either known to the researcher or

\footnotetext{
${ }^{1}$ Ethics approval was granted by Southern Cross University's Human Research Ethics committee.
} 


\section{DOLPHINS AND HUMAN FLOURISHING}

recruited through snowball sampling. Participants were briefed and informed consent obtained, predicated on using pseudonyms. Two of the potential participants withdrew from the study of their own accord; one became very unwell at the time of interviewing and was unable to participate, while the other withdrew for personal reasons-particularly that the memories of the dolphin interactions were too painful to discuss as the dolphin had died. The latter is important to consider when determining generalizability, in recognition that a close attachment with marine mammals may lead to negative emotions and may not enhance well-being and positive outcomes for all people.

The first author, an experienced psychologist, conducted and audio-recorded semistructured interviews with preformulated questions (Fig. 1). Idiographic (individually focused) reflective notes recorded observations of the interview experience (e.g., the interviewee's manners and affect). Rapport, flexibility and responsiveness encouraged areas of personal importance and meaning to be pursued in the narratives (Smith \&t Osborn, 2015).

\section{Design}

Interview narratives were examined using the qualitative method of interpretative phenomenological analysis (IPA). IPA focuses on the idiographic or individual human experiences and insights to comprehend people's subjective world within the wider sociocultural context (Larkin, Watts, \& Clifton, 2006). The researcher gains insights and understandings as the participants themselves make sense of their experiences (the "double hermeneutic" [Smith, 2004]). Data immersion was achieved through repeated exposure to the audio narratives, the making of extensive manual notes regarding interesting or significant comments or patterns and careful transcription into text analysis software (NVivoMac11). Data analysis followed standard interpretative phenomenological methods (Smith \& Osborn, 2015) involving several readings of the first interview transcript to look for pertinent and significant quotes, and repeating for the other transcripts (Crist \& Tanner, 2003) to identify emergent themes (Pietkiewicz \& Smith, 2014). Coding of each transcript identified conceptual connections between subthemes, which were grouped using descriptive labels (Figs. 1 and 2). Key statements and quotes were identified to exemplify the idiographic and common themes. Similar to other IPA studies (Dickson, Knussen, \& Flowers, 2008), the subthemes were considered recurrent if they emerged in at least half of the transcripts, which balanced the idiographic and the shared perspectives. The second author considered and coded sections of the transcripts via a data audit (Smith, Jarman, \& Osborn, 1999), to ensure that the codes were plausible and to test theme reliability and credibility. An iterative process of discussion ensued. Clatworthy,
Hinds, and Camic (2017) recently noted that the interpretative nature of IPA allows for some difference in opinion between coders, as long as the interpretations are overall considered credible.

\section{Results}

Five main themes emerged from the analyses: Connectedness, Relationships, and Reciprocity; Emotion and Aliveness; Meaning and Making Sense; Accomplishment and Intention; and Harmony and Engagement. Both individual and common themes are discussed, including prevalence and overlap (Table 2). To exemplify individual stories and compare narratives (Pietkiewicz \& Smith, 2014), representative quotes illustrate data interpretation (Elliot, Fischer, \& Rennie, 1999).

\section{Connectedness, Relationships, and Reciprocity}

Relationships and connectedness are crucial and interdependent contributors to human well-being (Seligman, 2011). Katcher and Wilkins (1993) describe how the human attraction to nature (biophilia) includes the propensity to interact with animals to ameliorate modern separation. Not surprisingly, the Connectedness, Relationships, and Reciprocity theme (referred to henceforth as Relationships) was the most prevalent, and its dominance is discussed further elsewhere (Yerbury \&t Boyd, 2018a).

Jacomo referred to the relationship he experienced as a result of interacting with a wild dolphin:

The dolphin was seeking out my attention ... I felt like it wanted to interact with me ... a feeling of that the dolphin preferred, at least in some instances, preferred to come back and to interact with me than with other people.

Relationships with animals was the most common subtheme, with all participants providing examples of how important these connections were for them. Brenda and Becky had the most references to this subtheme. This was likely due to Brenda being a long-term dolphin monitoring volunteer and Becky having daily contact with a solitary dolphin. Both had formed strong bonds with the dolphins. Brenda provides a response about her in-water experience with "girl" dolphins: "I had two of the girls that I know up alongside of me, and even in my snorkel, I'm like 'I love you' ... and I felt like they were connecting with me."

Proximity to dolphins involving physical touch or eye contact was an important element of connection with the wild animal for all participants. Brenda commented that "There was eye contact, sometimes on the boat as well ... you get that eye contact ... sometimes they will just roll over and have a look as if to say 'Yeah I see you' [laugh] 'I can hear you."' 


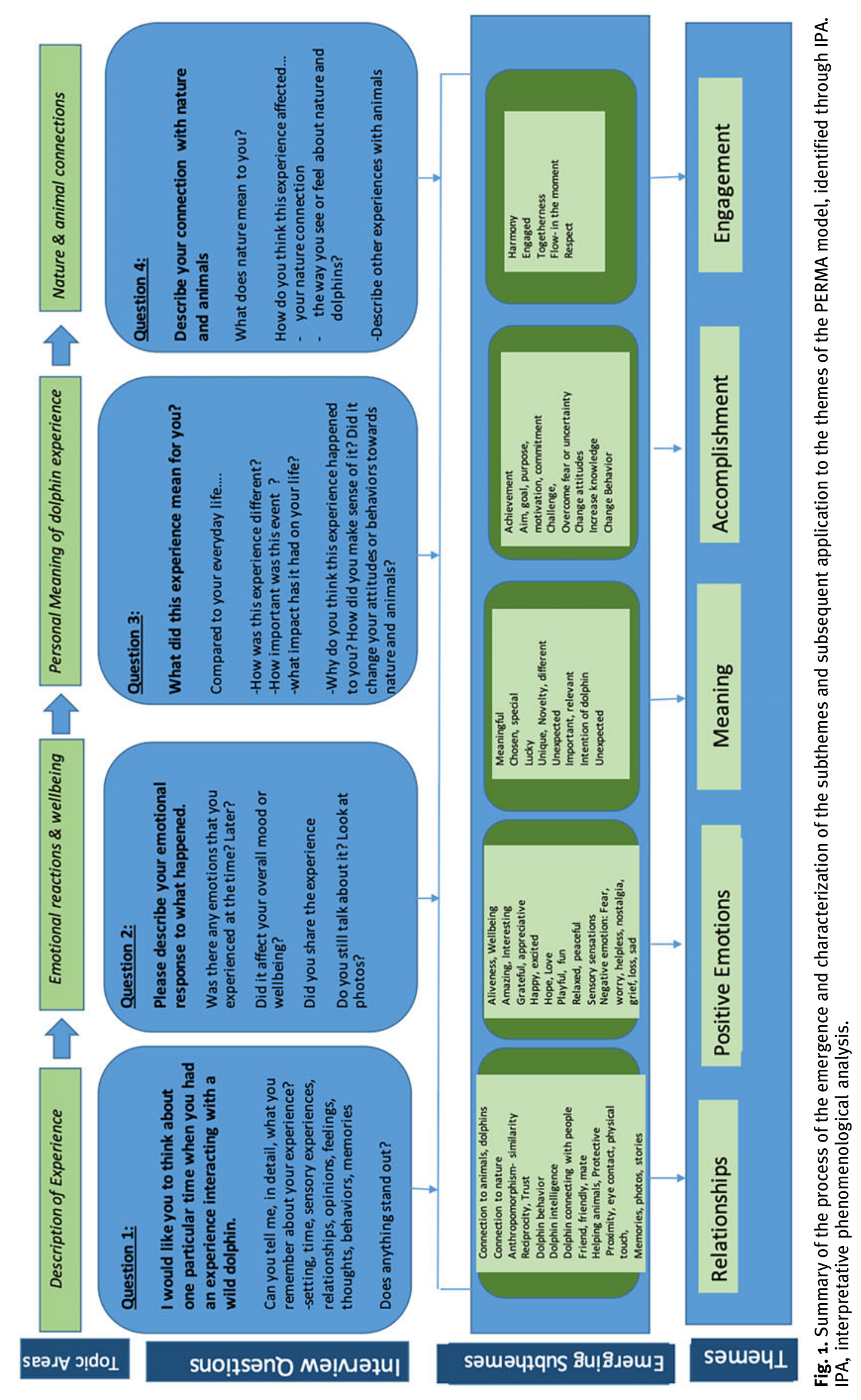




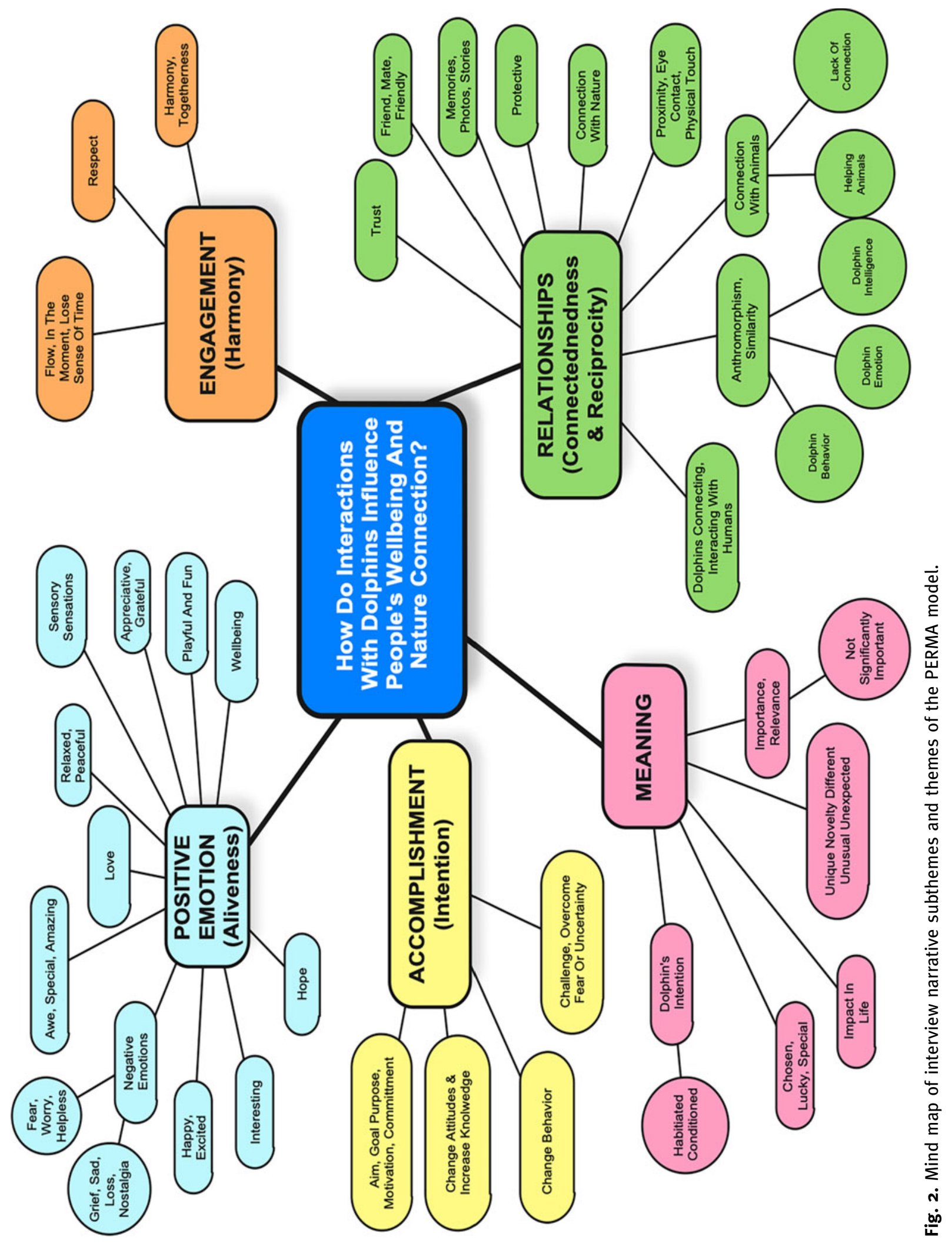




\section{YERBURY AND BOYD}

\begin{tabular}{|c|c|c|c|c|c|}
\hline THEME & RELATIONSHIPS & POSITIVE EMOTION & MEANING & ACCOMPLISHMENT & ENGAGEMENT \\
\hline Relationships & 339 & 77 & 45 & 24 & 38 \\
\hline Meaning & 45 & 33 & 125 & 7 & 10 \\
\hline Accomplishment & 24 & 25 & 7 & 84 & 2 \\
\hline
\end{tabular}

This theme overlapped strongly with other themes, particularly with Emotion and Aliveness. Jacomo spoke about the positive feeling the interaction evoked, raising both themes of connection and emotion in his comment: "I was, I guess amazed at how it would seek out that interaction, but also the physical contact, so it was it was quite a unique experience."

Meaning, which includes making sense of something to ascertain the personal impact, was regularly associated with Relationships. Jacomo, for example, explains how he made sense of his connection with the dolphin by drawing on his understanding that the dolphin's behavior comprised deliberate acts of engagement:

It felt, like, that on purpose, the dolphin would disappear, and I swear that it knew that everyone was standing there looking out across the water, waiting for the dolphin, ... and then it would just appear, right in your lap, like, not even an arm's length away, and so, it was just teasing us.

\section{Emotion and Aliveness}

Emotion and Aliveness was the second most frequent theme, with various emotions described: happiness appreciation, excitement, peace, amazement, and interest. Seligman (2011, p. 25) reminds us, "positive emotion is a subjective variable, defined by what you think and feel." Feelings of happiness and excitement when interacting with dolphins were the most common: "I was pretty excited, my heart was racing and I was smiling a lot" (Khaleesi); “Just the excitement ... I think it was just this excitement that I felt” (Anne); "It just felt amazing, you know, I mean you can tell by the way I am talking now, it gets you excited and it does give you that happy feeling" (Brenda).

Participants frequently described feelings of awe and wonder in response to being with dolphins, particularly Becky, for whom it was an unexpected experience: " $\mathrm{Oh}$, I thought the whole thing was magic, to me it was just an incredible experience, and something that you're never gonna get in your life again.”
Six of the participants expressed gratitude and appreciation "I felt very appreciative, very lucky, that I had had that opportunity" (Khaleesi). Brenda, who was the only participant to remark that the experiences improved her mental health, had the most expressions of gratitude: "since I've been with dolphins, I don't suffer nearly as much anxiety as I ever have ... it does make you generally appreciate."

Negative emotion was also a subtheme, and those raised were primarily about the participant feeling like they wanted to do more to help. "That became quite disheartening after a while, because there were too many I couldn't help" (Brenda). The negative emotion described also included the grief about dolphins who had died or had gone away and were missed (Anne, Brenda, Becky, Jim, Mark). Mark, for example, describes the mixed emotion of the dolphin no longer needing his help "that came at the expense of him severing his connection with you, and that was quite a powerful feeling of almost grief really." For others (Brenda, Becky, Khaleesi, Mark) the negative emotion involved worry for the safety or well-being of the dolphin or dolphins. "When you hear one's caught in a shark net, somewhere, I always think Aww .... I hope it's not her" (Becky).

There were also reports of negative emotions including fear and discomfort, which were transformed, in the participants' accounts, into positive experiences and emotions once overcome. These references are discussed in the Accomplishment section.

Meaning was also highly linked with Emotion. Molly commented, for example, that "It's the awe of our being there and stuff ... I guess that's the connection because you're with them in that process."

\section{Meaning and Making Sense}

Meaning and Making Sense of experiences was also a prevalent main theme. Subthemes (Fig. 2) included the impact, significance, importance, uniqueness, or personal relevance of the experience: "Lives may be experienced as meaningful when they are felt to have significance beyond the trivial or momentary, to have purpose" (King, 


\section{DOLPHINS AND HUMAN FLOURISHING}

Hicks, Krull, \&t Del Gaiso, 2006, p. 180). All interviewees referred to Meaning (as questions asked specifically about the meaning of the event), with some variation: "Meaningful? I don't really know how to answer that question. If you gave me a scale from one to ten, I would say it was an 8 or 9" (Khaleesi); "I think it's a significant thing to experience that connection with an animal like a dolphin" (Jacomo).

All participants acknowledged the specific personal importance or significance of the dolphin experience at least once, with Anne and Jim communicating this subtheme more than other interviewees. Their experiences were particularly individually meaningful, as Anne was making a film specifically about her experiences with a dolphin, and Jeff had devoted his life to dolphin conservation: "it's about having a greater sense of why you're doing it" ( Jim).

Meaning was articulated as privilege or luck, novelty and specialness, as the dolphins purposefully seeking human company, and was linked with positive emotions such as awe. Seven participants reference the experience as novel or unique:

The feelings you had were of privilege ... that you had the opportunity to have this kind of a close encounter with a totally wild animal ... it just it isn't something that many people have the opportunity to do and the fact that it was happening to me. (Mark)

Meaning's overlap with other themes was strongest with Relationships and Emotion, less so with Engagement. Mark refers to his particularly close experiences with a solitary dolphin he was rehabilitating. "Well it was very meaningful ... I think Jock became almost a part of my family."

Molly's narrative shows the links between the three themes of Meaning, Relationships, and Emotion as she describes the encounter:

I think the dolphin was seeking connections with people, as it was a solitary dolphin and didn't have its pod to be with, it would usually seek connections with other dolphins so it was seeking those connections with people ... It's not something that everyone gets to experience and it was really awesome that an animal that you don't encounter everyday wanted to spend time with us.

\section{Accomplishment and Intention}

Accomplishment and Intention was a less common main theme, defined as pursuing and achieving mastery, "motion towards a specific fixed goal" (Seligman, 2011, p. 113). All participants referred to accomplishment. There was a large variation depending on the extent and types of experiences; Molly provided the fewest references, due to her limited leisure encounters, whereas Jim (with the most references) had his life's work in the marine environment. Accomplish- ment included subthemes (Fig. 2) of commitment, motivation, or achievement of goals. Anne commented: "Personally it motivated me to do whatever I could, especially with the film, to get a message out ... that dolphins are sentient beings."

Participants also explained being proud of gaining mastery and overcoming challenges. In particular, Anne referred to this theme on two occasions: "I didn't end up feeling scared of him at the end, and I started trusting him, and you knew he trusted you."

Overlap with other themes included Emotion, and previous work links strong emotions and environmental behavior (Carter, 2011). Jim had the most references to this theme, likely because of his conservation work:

I think you feel positive about it, there's no question about that ... we felt like we had a good day [laughing] ... for us, it was just another, a positive outcome of what we do, but with a real spike to it that doesn't happen every day.

Brenda, who also works as a dolphin volunteer, expanded on this view by commenting that, "I think those sort of interactions do really strive to make you want to do better, not just for them but for yourself."

Six participants had references coded to the overlapping themes of Accomplishment and Relationships. Mark commented on his own change of perspective in the relationship: "Gee this guy needs some help, he hasn't got a very good quality of life at the moment, and that really changed from something he could do for me to swinging me around to what could I do for him."

\section{Harmony and Engagement}

The least common theme was Harmony and Engagement-mindful absorption in activities, being lost in the moment, a subjective flow state fully realized in retrospect (Nakamura \& Csikszentmihalyi, 2014). Experiences of nature engagement have been documented and linked with well-being (Capaldi et al., 2017). Participants described the feelings of mutuality-dolphins and people in harmony with each other and with nature. References from all participants included several from Anne, one in which she reflected on being in flow while interacting with the dolphin: "I was just snorkeling pretty much by myself, and the [dolphin] ... caught this fish, and gave it to me, and it all happened really slowly ... this dolphin is definitely making a connection with me."

Harmony and togetherness was the main subtheme; references include memories of interactions as games (Molly, Anne, Jacomo, Mark, Brenda) and perceptions of being in harmony or in tune (Becky). Six participants described the experience as being in the moment to the exclusion of all else, not noticing, for example, cold or discomfort. This situation reflects the experience of flow, derived 


\section{YERBURY AND BOYD}

from being fully engaged in the experience. Jacomo and Khaleesi, who both had brief experiences with only one solitary sociable dolphin, reflected on the depth of their experiences:

Jacomo talked about flow through his lack of noticing cold. "I didn't kind of think about it," he explained,

I didn't really know that I wasn't noticing the cold until after, and then you would feel cold and have to get out, so I think that maybe thinking about the dolphin and the experience, you weren't thinking about the cold.

Khaleesi reflected on ceasing to think about routines: "I could just experience something without having to think and just go with the flow, without thinking about particular routines or anything like that."

Engagement overlapped with Emotion and Relationships. Being mindfully involved in nature has been shown to decrease negative emotions (Nisbet, Zelenski, \& Grandpierre, 2019) and to increase positive affect (Stewart \& Haaga, 2018). Animals have also been found to engage attention particularly when a sense of kinship is ascribed or assumed (Katcher \&t Wilkins, 1993). Again, Jacomo and Khaleesi provide examples of engagement with dolphins. Jacomo commented that, "it wasn't the same as spending time watching whales and dolphins in the wild as you would normally do, and this was more like spending time.” Despite the brevity of her experience, intimacy and positive emotion were reflected in Khaleesi's comment:

I just really appreciated I'd had the opportunity to swim with the dolphin, ... so it was a really intimate kind of experience for me, and I felt very appreciative, very lucky, that I had had that opportunity, and I was just on a high I guess all the way home.

In summary, the main themes are shown to be highly interrelated and interdependent in varying degrees of importance and strength of connectivity (Fig. 3).

\section{Discussion}

Through the examination of participants' recollections and expressions of lived experiences, this study offers insight into the

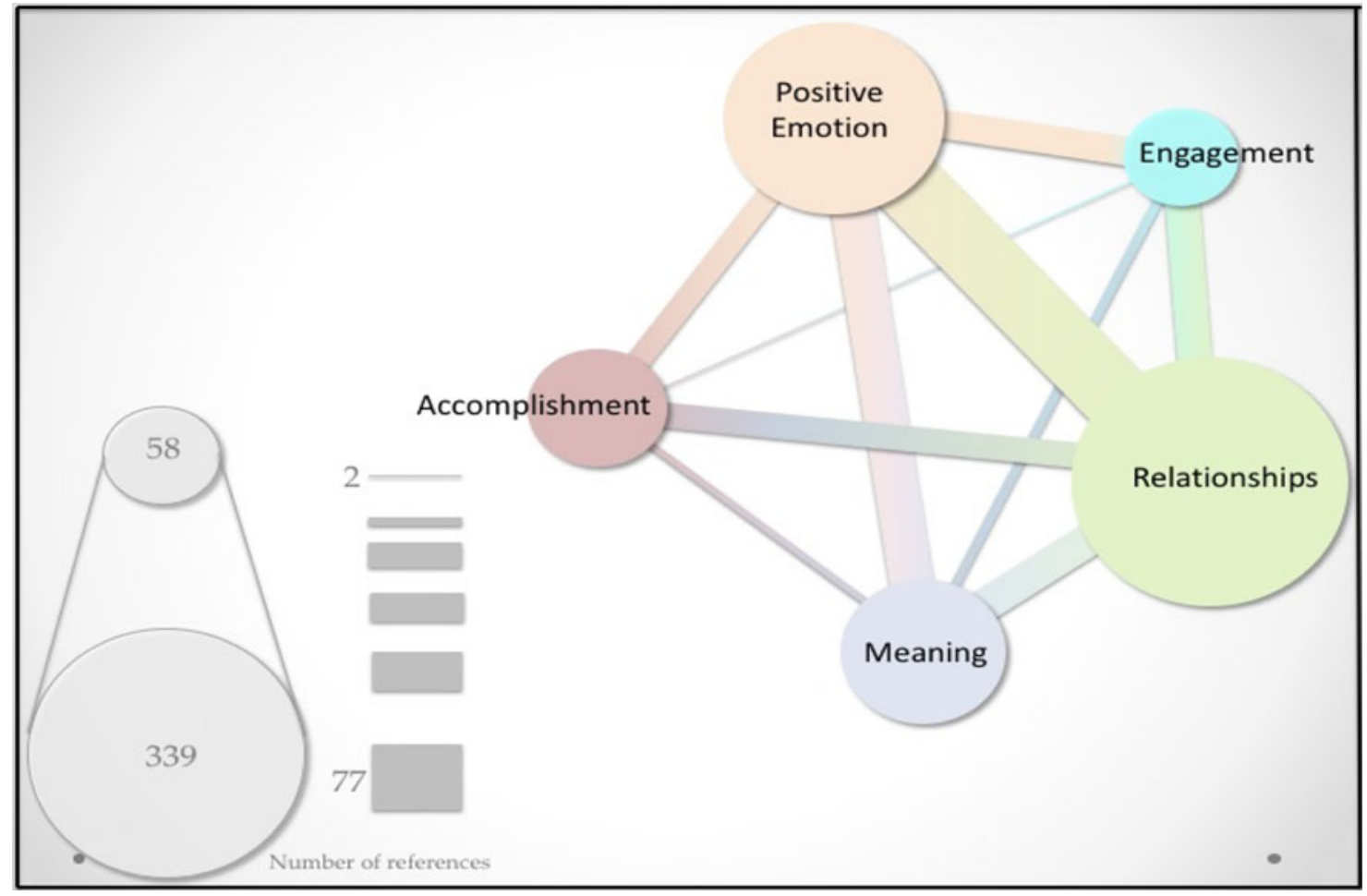

Fig. 3. Relative importance of the five PERMA themes and strength of association between themes. This plot indicates the relative importance of both the individual themes and their associations, based on the numbers of references in interview transcripts. These values differentiate sufficiently to provide a valid impression of the relative strength of each theme. 


\section{DOLPHINS AND HUMAN FLOURISHING}

phenomenon of human interactions with wild dolphins, and its effect on multiple dimensions of human well-being. While this discussion primarily focuses on human perceptions and benefits, the aim is to provide a conversation recommending mutually beneficial connections with wildlife rather than utilization and commodification.

For humans, the human-dolphin nature interaction promotes positive relationships, feelings and perceptions through engagement with another species, which in turn help the individual create meaning and purpose in their life, sometimes leading to motivation and achievement for proenvironmental behaviors. As expected, participants expressed their idiosyncratic stories through unique experiences and interpretations with commonalities, suggesting that interactions with dolphins in nature can have a significant effect on human well-being.

After the analyses were complete, parallels between the generated themes and Seligman's (2011) PERMA model were observed. Larkin et al. (2006) discusses the appropriateness of positioning IPA results within theoretical models, and Smith (2017) discusses this in relation to positive psychological frameworks. Recent research supports the validity of the PERMA model (Roepke \&t Seligman, 2015), and its utility in considering the well-being effects of a range of activities (e.g., Ascenso, Williamon, \& Perkins, 2016). The current study extends the model's applications into human experiences with animals.

In considering the idiographic themes generated from participant accounts, certain individual narratives were more focused on particular themes, depending on their personal level of interaction with dolphins and how this experience was positioned within their life. Common themes and ideas were able to be generated from the idiographic analyses. One particular commonality between all narratives was the experience of emotion, including happiness, hope, and appreciation, both immediate and enduring. The interpretation is that positive emotions create cognitive changes, triggering ongoing effects (Fredrickson \& Losada, 2005), specifically positive functioning and flourishing (Garland et al., 2010). The solid link between Emotion and Accomplishment here supports this theory: Participants reported intense emotion providing motivation for conservation behavior (Carter, 2011).

The strong, idiographic emotional descriptions are testament to the intensity of the attachments between participants and dolphins. Emotion is highly dependent on the relational meaning that the individual constructs from an interchange (Lazarus, 2006). The strength of connection between Emotion and Relationship (Fig. 3) extends previous findings about the significance of human-animal relationships for well-being (Beetz et al., 2012; Walsh, 2009; Yerbury et Boyd, 2018a).
The theme of Relationships was particularly important in the human-dolphin interaction; it accounted for over $40 \%$ of participant commentary. This is hardly surprising, as Kahn (2009) reflects: Humans have always sought interaction and attention from animals. The importance of positive relationships for flourishing has been previously identified (e.g., Diener \&t Seligman, 2002). Although such studies relate to human-human social contact, this study raises the potential that wild animals may be able to fulfil satisfying connections for some people. As Katcher and Wilkins (1993) eloquently state, "Creating a kinship with animals .... made the world a more comfortable place by reducing human isolation” (p.187).

The connection perceived toward dolphins and the natural environment contributed to a sense of engagement in the encounter, which influenced positive participant descriptions. Engagement is interpreted here as humans interacting with nature in harmony (rather than merely observing), which is an important component of both well-being (Capaldi et al., 2017) and proenvironmental behavior (Tam, 2015).

Wild nature experiences in this study, similar to previous research, encompassed feelings of awe (Davis \& Gatersleben, 2013), being in the flow, and harmony and connection with wildlife (Birtles, Valentine, Curnock, Arnold, \& Dunstan, 2002; Curtin, 2006; DeMares, 2000; Packer \& Ballantyne, 2012; Webb \& Drummond, 2001). Participants who reported feelings of harmony with the dolphin were more likely to see the experience as meaningful (Nakamura \&t Csikszentmihalyi, 2014). While the participants in this study did not specifically describe life-changing or transcendent experiences (Snell \& Simmonds, 2012), they did talk at length about feelings of awe, flow, and harmony, which triggered a powerful sense of individual meaning of encounters.

Having meaning in one's life is essential for psychological wellness and flourishing (Frankl, 1959/2006; Ryff \& Singer, 2008; Seligman, 2011) and for feeling connected with nature (Howell, Passmore, \& Buro, 2013). Furthermore, a sense of nature helps us understand ourselves: "Loss of the wild other leaves nothing but our own image to explain ourselves by" (Shephard, 1993, p. 294). Direct experiences with wildlife can allow meaningful connections to develop (Myers \& Saunders, 2002), and in our study this was important in participants' making sense of their dolphin recollections. Participants speculated about the dolphin's intentions, or explained the dolphin's behavior in human terms, and this anthropomorphism is interpreted as participants applying their own human frame of reference. Anthropomorphism may lead to an increase in moral concern, proenvironmental effects, and care (Katcher \& Wilkins, 1993; Tam, 2015; Waytz, Cacioppo, \& Epley, 2010). Conversely, anthropomorphism can lead to inaccurate 


\section{YERBURY AND BOYD}

portrayals of animals which distance people from reality (Ganea, Canfield, Simons-Ghanfari, \& Chou, 2014) and serve to frame animals as extensions of humankind rather than inherently valuable in their own right (Wiener, 2015). Anthropomorphism, therefore, may have mixed benefits and may affect meaning in different ways for different people (Waytz et al., 2010).

Often the encounter was determined to be unique or novel, adding to the perceived importance of the event's meaning. The impact on participants' lives varied. For some, the dolphin experience was just one of many positive nature experiences, while for others it was pivotal, if not necessarily life-changing. Meaning is, therefore, individually contingent. Cognitive appraisal of meaning also influences the degree of emotional reaction. This supports literature linking meaning, positive emotions, and mood (Keyes, Shmotkin, \& Ryff, 2002; King et al., 2006). Meaningful pursuits allow an individual to engage and accomplish goals (Ganzevoort \& van den Born, 2019), in turn benefitting well-being (Schueller \& Seligman, 2010). A risk of highlighting human benefits from wildlife contact is the potential that it perpetuates an argument for continuing utilization of wildlife for human benefit (Shephard, 1993). The data in the current study points toward participants understanding the importance of a balanced, ecocentric approach, evidenced by many comments on the importance of nature and respect for wildlife and the drive to make a difference. Accomplishment featured in all participants' narratives and was related to having a purpose or goal, ranging from simply wanting to interact with dolphins to developing knowledge to devoting one's life to conservation. Reaching one's objectives is associated with happiness and well-being (Jayawickreme, Forgeard, \& Seligman, 2012), highlighting links between Accomplishment and Emotion which also overlapped with Relationships. The AccomplishmentRelationships association was strongest for the three participants involved in dolphin conservation, therefore affirming that when one has a connection with nature, one is more likely to want to protect it or vice versa (Duckworth, Peterson, Matthews, \& Kelly, 2007).

This study supports previous research linking human well-being benefits of contact and connection with nature and animals (Bernabei et al., 2013; Geist, 2013; Melson, 2003). Such findings may encourage health practitioner use of nature prescriptions as a part of lifestyle prescriptions (ADGP, 2005), including recommendations for contact with wildlife and other animals. This practice is substantiated by reports of therapeutic benefits for humans interacting with captive and domesticated animals and wildlife (e.g., Antonioli \&t Reveley, 2005; Beetz et al., 2012; Katcher \& Wilkins, 1993; Muloin, 1998; Webb \& Drummond, 2001) and could be a cost-effective alternative to medication (Frumkin et al., 2017). Therapeutic wildlife prescrip- tions for psychological well-being, while not well represented in the literature, may therefore be a field worthy of further research within an ecocentric framework. However, these interventions would not be appropriate for large amounts of people, due to the potential environmental and wildlife impacts. There may be, therefore, alternative, less impactful, and more ecocentric ways to manage such interventions, and this could be an area of further investigation.

This study allows for the possibility that dolphins could be unique in triggering well-being effects possibly due to the long-standing and sacred nature of human-dolphin connection across history (Servais, 2005). In the light of this possibility, additional studies that consider the well-being effects of other types of wildlife are needed to test assumptions of both generalizability and uniqueness of the dolphin experience. This study suggests that the benefits of wildlife interactions are idiosyncratic in their effectiveness, with some shared commonalities between people, and may be beneficial for certain individuals.

\section{Conclusion}

This paper demonstrates that the multiple features of life necessary for human well-being and flourishing (Seligman, 2011) may be fulfilled by human experiences of interacting with nature and dolphins for some individuals. Applying the PERMA model provides a good fit in describing and interpreting narratives of human-dolphin interactions. This study therefore suggests that people's interactions with wild animals in their natural settings may uniquely contribute to nature connection and well-being and, in turn, create the impetus for conservation. It is important to frame these human benefits ecocentrically, so that nature and wildlife are not viewed as valuable only in relation to human advantage. This has practical implications for the pursuit of flourishing and provides further evidence for the benefits of nature and animal contact in reaching well-being goals.

\section{Author Disclosure Statement}

No competing financial interests exist.

\section{Funding Information}

No funding was received for this article.

\section{REFERENCES}

ADGP. (2005). Lifestyle prescriptions information sheet. Forrest, Australia: Australian Divisions of General Practice.

Antonioli, C., \& Reveley, M. A. (2005). Randomised controlled trial of animal facilitated therapy with dolphins in the treatment of depression. British Medical Journal, 331, 2-4. 


\section{DOLPHINS AND HUMAN FLOURISHING}

Ascenso, S., Williamon, A., \& Perkins, R. (2016). Understanding the wellbeing of professional musicians through the lens of positive psychology. Psychology of Music, 45, 65-81.

Beetz, A., Uvnas-Moberg, K., Julius, H., \& Kotrschal, K. (2012). Psychosocial and psychophysiological effects of human-animal interactions: The possible role of oxytocin. Frontiers in Psychology, 3, doi:10.3389/fpsyg.2012.00234

Bernabei, V., De Ronchi, D., La Ferla, T., Moretti, F., Tonelli, L., Ferrari, B., ... Atti, A. R. (2013). Animal-assisted interventions for elderly patients affected by dementia or psychiatric disorders: A review. Journal of Psychiatric Research, 47, 762-773.

Birtles, A., Valentine, P., Curnock, M., Arnold, P., \& Dunstan, A. (2002). Incorporating visitor experiences into ecologically sustainable $d$ warf minke whale tourism in the northern Great Barrier Reef (CRC Reef Research Centre Technical Report 42). Townsville, Australia: CRC Reef Research Centre Ltd.

Burns, G. L. (2015) Animals as tourism objects: Ethically refocusing relationships between tourists and wildlife. In C. Cooper (Series Ed.), Aspects of Tourism: Vol. 67. Animals and Tourism: Understanding diverse relationships. (67th ed., pp. 44-59). Bristol, UK: Channel View.

Capaldi, C. A., Passmore, H.-A., Ishii, R., Christopolskaya, K. A., Vowinckel, J., Nikolaev, E. L., \& Semikin, G. I. (2017). Engaging with natural beauty may be related to well-being because it connects people to nature: Evidence from three cultures. Ecopsychology, 9, 199-211.

Carter, D. M. (2011). Recognizing the role of positive emotions in fostering environmentally responsible behaviors. Ecopsychology, 3, 65-69.

Clatworthy, J., Hinds, J., \& Camic, P. M. (2017). Exploring the relationship between suburban allotment gardening and well-being: An interpretative phenomenological analysis. Ecopsychology, 9, 121-129.

Crist, J. D., \& Tanner, C. A. (2003). Interpretation/analysis methods in hermeneutic interpretive phenomenology. Nursing Research, 52, 202-205.

Curtin, S. (2006). Swimming with dolphins: A phenomenological exploration of tourist recollections. International Journal of Tourism Research, 8, 301-315.

Curtin, S., \& Kragh, G. (2014). Wildlife tourism: Reconnecting people with nature. Human Dimensions of Wildlife, 19, 545-554.

Davis, N., \& Gatersleben, B. (2013). Transcendent experiences in wild and manicured settings: The influence of the trait "connectedness to nature." Ecopsychology, 5, 92-102

DeMares, R. (2000). Human peak experience triggered by encounters with cetaceans. Anthrozoos: A Multidisciplinary Journal of The Interactions of People \&t Animals, 13, 89-103.

Dickson, A., Knussen, C., \&t Flowers, P. (2008). 'That was my old life; it's almost like a past-life now': Identity crisis, loss and adjustment amongst people living with Chronic Fatigue Syndrome. Psychology \& Health, 23, 459-476.

Diener, E., \& Seligman, M. E. (2002). Very happy people. Psychological Science, 13, $81-84$.

Duckworth, A. L., Peterson, C., Matthews, M. D., \& Kelly, D. R. (2007). Grit: Perseverance and passion for long-term goals. Journal of Personality and Social Psychology, 92, 1087-1101.

Elliot, R., Fischer, C. T., \&t Rennie, D. L. (1999). Evolving guidelines for publication of qualitative research studies in psychology and related fields. British Journal of Clinical Psychology, 38, 215-229.

Frankl, V. (2006). Man's search for meaning: An introduction to logotherapy (4th ed.). Boston, MA: Beacon Press Books. (Original work published 1959)

Fredrickson, B., \& Losada, M. (2005). Positive affect and the complex dynamics of human flourishing. American Psychologist, 60, 678-686.
Frumkin, H. (2001). Beyond toxicity: Human health and the natural environment. American Journal of Preventative Medicine, 20, 234-240.

Frumkin, H., Bratman, G. N., Breslow, S. J., Cochran, B., Kahn, P. H., Jr., Lawler, J. J., ... Wood, S. A. (2017). Nature contact and human health: A research agenda. Environmental Health Perspectives, 125, doi:10.1289/ehp1663

Ganea, P. A., Canfield, C. F., Simons-Ghanfari, K., \&t Chou, T. (2014). Do cavies talk? The effect of anthropomorphic picture books on children's knowledge about animals. Frontiers in Psychology, 5, 1-9.

Ganzevoort, W., \& van den Born, R. (2019). The thrill of discovery: Significant nature experiences among biodiversity citizen scientists. Ecopsychology, 11, doi:10.1089/ eco.2018.0062

Garland, E. L, Fredrickson, B., Kring, A. M., Johnson, D. P., Meyer, P. S., \& Penn, D. L. (2010). Upward spirals of positive emotions counter downward spirals of negativity: Insights from the broaden-and-build theory and affective neuroscience on the treatment of emotion dysfunctions and deficits in psychopathology. Clinical Psychology Review, 30, 849-864.

Geist, T. S. (2013). An exploratory study of the therapeutic elements that operate between therapy dogs and students with mental health disorders (Unpublished doctoral dissertation). School of Human Service Professions, Widener University, Chester, PA.

Hartig, T., \& Kahn, P. H., Jr. (2016). Living in cities, naturally. Science, 352, 938-940. Howell, A. J., Passmore, H., \&t Buro, K. (2013). Meaning in nature: Meaning in life as a mediator of the relationship between nature connectedness and well-being. Journal of Happiness Studies, 14, 1681-1696.

Jayawickreme, E., Forgeard, M. J., \& Seligman, M. E. (2012). The engine of well-being. Review of General Psychology, 16, 327-342.

Kahn, P. H., Jr. (1997). Developmental psychology and the biophilia hypothesis: Children's affiliation with nature. Developmental Review, 17, 1-61.

Kahn, P. H., Jr. (2009). Cohabitating with the wild. Ecopsychology, 1, 38-47.

Katcher, A., \& Wilkins, G. (1993). Dialogue with animals: Its nature and culture. In S. Kellert \& E. O. Wilson (Eds.), The biophilia hypothesis (pp. 173-197). Washington, DC: Island Press.

Kellert, S. R. (1996). The value of life: Biological diversity and human society. Washington, DC: Island Press.

Keyes, C. L., Shmotkin, D., \& Ryff, C. D. (2002). Optimizing well-being: The empirical encounter of two traditions. Journal of Personality and Social Psychology, 82, 1007-1022.

King, L. A., Hicks, J. A., Krull, J. L., \& Del Gaiso, A. K. (2006). Positive affect and the experience of meaning in life. Journal of Personality and Social Psychology, 90, 179-196.

Larkin, M., Watts, S., \& Clifton, E. (2006). Giving voice and making sense in interpretative phenomenological analysis. Qualitative Research in Psychology, 3, 102-120.

Lazarus, R. S. (2006). Emotions and interpersonal relationships: Toward a person-centered conceptualization of emotions and coping. Journal of Personality, 74, 9-46.

Maslow, A. H. (1954). Motivation and personality. New York, NY: Harper.

Melson, G. F. (2003). Child development and the human-companion animal bond. The American Behavioral Scientist, 47, 31-39.

Muloin, S. (1998). Wildlife tourism: The psychological benefits of whale watching. Pacific Tourism Review, 2, 199-213.

Myers, O. E., \& Saunders, C. D. (2002). Animals as links toward developing caring relationships with the natural world. In P. H. Kahn \& S. Kellert (Eds.), Children and nature (pp. 153-179). Cambridge, MA: MIT Press. 


\section{YERBURY AND BOYD}

Nakamura, J., \& Csikszentmihalyi, M. (2014). The concept of flow. In M. Csikszentmihalyi (Ed.), Flow and the foundations of positive psychology (pp. 239-264). Dordrecht, the Netherlands: Springer.

Nisbet, E. K., Zelenski, J. M., \&t Grandpierre, Z. (2019). Mindfulness in nature enhances connectedness and mood. Ecopsychology, 11, doi:10.1089/eco.2018.0061

Packer, J., \& Ballantyne, R. (2012). Comparing captive and non-captive wildlife tourism. Annals of Tourism Research, 39, 1242-1245.

Patton, M. (1999). Enhancing the quality and credibility of qualitative analysis. Health Services Research, 34, 1189-1208.

Pietkiewicz, I., \& Smith, J. A. (2014). A practical guide to using interpretative phenomenological analysis in qualitative research psychology. Czasopismo Psychologiczne Psychological Journal, 20, 7-14.

Roepke, A. M., \& Seligman, M. E. (2015). Doors opening: A mechanism for growth after adversity. The Journal of Positive Psychology, 10, 107-115.

Rogers, C. (1977). Carl Rogers on personal power. New York, NY: Delacorte.

Ryff, C. D., \& Singer, B. H. (2008). Know thyself and become what you are: A eudaimonic approach to psychological well-being. Journal of Happiness Studies, 9, 13-39.

Schueller, S. M., \& Seligman, M. E. P. (2010). Pursuit of pleasure, engagement, and meaning: Relationships to subjective and objective measures of well-being. The Journal of Positive Psychology, 5, 253-263.

Seligman, M. E. (2011). Flourish: A visionary new understanding of happiness and well-being. New York, NY: Free Press.

Servais, V. (2005). Enchanting dolphins: An analysis of human-dolphin encounters. In J. Knight (Ed.), Animals in person. Cultural perspectives on human-animal intimacies (pp. 323-349). Oxford, UK: Berg.

Shephard, P. (1993). Our animal friends. In S. Kellert \&t E. O. Wilson (Eds.), The biophilia hypothesis (pp. 275-300). Washington, DC: Island Press.

Smith, J. A. (2004). Reflecting on the development of interpretative phenomenological analysis and its contribution to qualitative research in psychology. Qualitative Research in Psychology, 1, 39-54.

Smith, J. A. (2017). Interpretative phenomenological analysis: Getting at lived experience. The Journal of Positive Psychology, 12, 303-304.

Smith, J. A., Jarman, M., \& Osborn, M. (1999). Doing interpretative phenomenological analysis. In M. Murray \& K. Chamberlain (Eds.), Qualitative health psychology (pp. 218-240). London, UK: Sage.

Smith, J. A., \&t Osborn, M. (2015). Interpretative phenomenological analysis. In J. A. Smith (Ed.), Qualitative psychology: A practical guide to research methods (pp. 53-80). London, UK: Sage.

Snell, T. L., \&t Simmonds, J. G. (2012). "Being in that environment can be very therapeutic": Spiritual experiences in nature. Ecopsychology, 4, 326-335.

Stewart, M., \&t Haaga, D. A. F. (2018). State mindfulness as a mediator of the effects of exposure to nature on affect and psychological well-being. Ecopsychology, $10,53-60$.
Tam, K.-P. (2015). Mind attribution to nature and proenvironmental behavior. Ecopsychology, 7, 87-95.

Walsh, F. (2009). Human-animal bonds I: The relational significance of companion animals. Family Process, 48, 462-480.

Waytz, A., Cacioppo, J., \& Epley, N. (2010). Who sees human? The stability and importance of individual differences in anthropomorphism. Perspectives on Psychological Science, 5, 219-232.

Webb, N. L., \& Drummond, P. D. (2001). The effect of swimming with dolphins on human well-being and anxiety. Anthrozoös: A Multidisciplinary Journal of the Interactions of People and Animals, 14, 81-85.

Weiler, B. V., Ham, S. H., \& Smith, L. D. G. (2011). The impacts of profound wildlife experiences. Anthrozoös: A Multidisciplinary Journal of the Interactions of People and Animals, 24, 51-64.

Wiener, C. (2013). Friendly or dangerous waters? Understanding dolphin swim tourism encounters. Annals of Leisure Research, 16, 55-71.

Wiener, C. (2015). Dolphin tourism and human perceptions: Social considerations to assessing the human-dolphin interface. In K. Markwell (Ed.), Animals and tourism: Understanding diverse relationships (pp. 146-163). Bristol, UK: Channel View.

Yerbury, R. M., \& Boyd, W. E. (2018a). Human-dolphin interactions: Relationships, connections, and the reinforcement of an ongoing nature relationship. Anthrozoös: A Multidisciplinary Journal of the Interactions of People and Animals, 31, 443-458.

Yerbury, R. M., \& Boyd, W. E. (2018b). Wild dolphins, nature and leisure: Whose wellbeing? In N. Carr \& J. Young (Eds.), Wild animals and leisure: Rights and welfare (pp. 149-164). New York, NY: Routledge.

Yerbury, R. M., Boyd, W. E., Lloyd, D., \& Brooks, A. (2017). Right to leisure? Refocusing on the dolphin. Annals of Leisure Research, 20, 368-385.

Address correspondence to: Rachel M. Yerbury

Southern Cross University

Department of Environment, Science and Engineering

PO Box 157

Lismore, NSW 2477

Australia

E-mail: r.yerbury.10@student.scu.edu.au

Received: February 24, 2019

Accepted: May 5, 2019 